\title{
DYSFUNCTIONAL STATE AND SEVERANCE IN AFRICA: AN ANALYSIS IN SPECIFICITIES AND CONTRADICTIONS
}

\section{Makodi Biereenu-Nnabugwu \& Jaja Nwanegbo*}

http://dx.doi.org/10.4314/og.v9i1.7

\section{Abstract}

This paper identifies and examines two interrelated contradictions that affect Africa's contemporary material existence. They are dysfunctional or inorganic state and its structures and manipulated severance from Africa's roots. The paper aligns with the quest for a platform that provides more than a cursory prism for veritable insight into specificities and contradictions in the context of contemporary Africa. Anchored in Alavi's theory of overdeveloped state, the paper is essentially an exploratory analysis of Africa's concrete situation.

Key words and phrases: inorganic state structures, dysfunction, manipulated severance, contradictions and Africa's roots

\section{Introduction}

Caught in the web of vicious circles of instability and civil wars, particularly since the 1990s, today's Africa is considered, by many, as the most intriguing. In a near paradox, Africa is also easily the least understood and indeed the least explained. Why is the situation the way it is? In this paper, we may not be able to fully explain why Africa is what it is, or details on what Africa has been and how Africa came to be what she is today. The paper is hinged on the quest for a platform that provides more than a cursory prism for veritable 
Nnabugwu \& Nwanegbo: Dysfunctional State and Severance in Africa insight into specificities and contradictions in the context of contemporary Africa. In particular, what is the character of the state and its structures in contemporary Africa? What is the nature of Africa's severance from her roots and what is the import of this on Africa's quest for development and underdevelopment. What can be done?

In response to the foregoing, this paper identifies and examines some interrelated and prominent characteristics or factors that affect Africa's contemporary material existence. They are dysfunctional or inorganic state and its structures and manipulated severance from Africa's roots. The essential task is thus to explore and put each of the two factors in perspective in the attempt to characterize contemporary Africa.

The paper is essentially an exploratory analysis of Africa's concrete situation. To this end, the paper is divided into five interrelated sections. The first section is essentially this brief introduction of the subject of the study. It is followed by a discourse of key theoretical and contextual issues. The third section dwelt on the inorganic and dysfunctional state structures while the fourth looks at the fact of Africa's manipulated severance from her worthy roots. The fifth part is the concluding analysis and it contains our summary, recommendations and conclusion.

\section{Conceptual and Contextual Issues}

This paper is anchored on the theory of overdeveloped state. Simply stated, the theory posits that there is excessive enlargement of powers of control and regulation that the state has accumulated and elaborated which extend far beyond the logic of what may be necessary for orderly functioning of the social institutions of the society which the state presides. In his study "State and Class", Alavi (in Alavi and Shanin, ed, 1982: 301 ) points to the fact that there is a considerable accretion of 
Ogirisi: a new journal of African studies vol 92012 power of control and regulation in peripheral capitalist formations. In particular, he states that:

unlike in the advanced capitalist countries where the state that has developed in the wake of a single dominant class and therefore 'subordinate' to it, we find that in peripheral capitalist countries, there is instead a very considerable accretion of powers of control and regulation over the 'dominant' fundamental classes in the hands of a powerful and centralized state; here the fundamental classes do not have direct control over the state.

The overdeveloped state phenomenon hinges on the logic that the state in Africa has powers that are far beyond what is necessary for their functioning. This is essentially because, being postcolonial states, foreign bourgeoisies constitute powerful elements in the class structure of African states. This is due primarily to the fact that in its economic quest, the foreign bourgeoisie used the colonial state apparatuses to subjugate all the indigenous social classes. In line with this, Alavi (1972:61) argues that:

it might be said that the 'super-structure' in the colony, is therefore 'overdeveloped' in relation to the structure in the colony, for its basis lies in the metropolitan structure itself, from which it is later separated at the time of independence ... The postcolonial state inherits that overdeveloped apparatus of the state and its institutionalized practices through which the operations of the indigenous social classes are regulated and controlled. 
Nnabugwu \& Nwanegbo: Dysfunctional State and Severance in Africa

The postcolonial state is thus not only overdeveloped, it is also relatively autonomous and at the same time not an instrument of a single class, yet it plays prominent economic roles. It mediates between the competing interests of the metropolitan and indigenous bourgeoisie who see the state as a means of superintending wealth and source of primitive accumulation respectively.

As has often been emphasized, European activities and supremacy at global stage and her exploitation and appropriation of other lands and peoples are no doubt critical factors in Europe's pre-eminence. All these grew steadily from the sixteenth century. It is equally important to point out straight away that Europe's discovery of classical writings particularly those of Plato and Aristotle were instrumental to Europe's pre-eminence in their post-medieval period. Thus, whereas Europe rediscovered herself after roughly a thousandyear of self inflicted hiatus in what is now known as Dark or Medieval Age, for the contemporary Africa, it is a different ball game. This they achieved through the writings of such eminent thinkers as St Thomas Aquinas, Nicollo Machiavelli, John Locke, Thomas Hobbes, Jean-Jacques Rouseau, Jean Bodin, Hugo Grotius, Adam Smith, Karl Marx and a host of others. Contemporary Africa has not been able to come to terms with her past, let alone harness its strengths. Indeed, while developments in the Renaissance/Industrial Revolution period were largely a maturation of home-brewed and fermented thinking by Europe; in Africa, it is a different situation. There is hardly any meaningful link with the roots in the case of Africa. Accordingly, we hypothesize that contemporary Africa is adversely affected by the contradictions of inorganic state structures and manipulated severance from the roots. 
Ogirisi: a new journal of African studies vol 92012

\section{Inorganic and Dysfunctional State Structures}

A major character of the contemporary Africa is the pervasive and overwhelming presence of inorganic and dysfunctional states and structures. As a matter of fact, all, but one state, Ethiopia in present Africa, are products of foreign domination in the continent. Ethiopia is not only the surviving ancient African state but also ranks among the rare group of states with a history of over two thousand years. In particular, Ethiopians challenged and defeated Italian attempts to annex and colonize them through many fierce battles. Other (ore-contact) states were however, not that lucky, they were within the same period either through outright defeat, treachery or conquest cowed into submission, distortion or outright destruction.

Unlike in Europe, where the status of most of the existing states were agreed upon and guaranteed, at least in principle by the 1648 Treaty of Westphalia, the present day African states emerged at the instance and interest of nonAfrican powers. Following the 1884/5 meeting of major contending powers in Europe, convened by Germany, pencil lines were used to invent, decree and allot (what later became African states) areas of influence to various European powers. Therefore, the states that came to be did so by fiat and indeed in response and in the interest of outsiders (see picture of the real situation in Ferrante, 2003: 6-7). Thus, they emerged without consideration of what the people of Africa wanted or wished.

The implication of the foregoing is that contemporary African states are overwhelmingly pervasive and yet not autochthonous. Not only are they not products of social interplay between internal contending forces, the fact is also that the prevailing state structures and apparatuses are foreign and accordingly relate only artificially and superficially with the indigenous societal values and processes (see also 
Nnabugwu \& Nwanegbo: Dysfunctional State and Severance in Africa Nwanegbo, 2005). Not having any correlation with the dynamics of the autochthonous social forces and institutions, the emergent African states have had to hang tenaciously on mechanistic relations and processes.

Unlike in the previous stages in Africa's heritage where virtually all states emerge or dismember as specific or isolated event, the same cannot be said of contemporary African states. The emergence of contemporary states in Africa can be likened to major or mega-burns - instantaneous, widespread, overwhelming and difficult to treat or heal. Contemporary states and their structures in Africa appeared suddenly and yet substantially exogenous and all encompassing. As expected, they do not have organic relationship with indigenous social life and values (see again Olisa and Nwanegbo, 2006).

Equally important is the fact that in contemporary Africa, states exist as abstract or strange entities with predatory personality. They appear and exist as predatory public forces represented by coercive apparatus in their relationship with their preys (citizens). Consequently, contemporary state institutions and apparatuses particularly those responsible for governance are often viewed from the prism of 'theirs' rather than 'ours' syndrome. No doubt this is connected with the specificity of post-medieval European colonial subjugation and enterprise in Africa. Taking due cognizance of this, Preiswerk and Perrot (1978:72) much as Fanon (in Zehar, 1974) point out that violence and "the legitimation of aggression in the name of civilization was particularly widespread during the period of colonial expansion".

Although attempts have been made to domesticate this strange public force, as in Thomas Sankara's Burkina Faso, the prevailing order has been increasing monsterization of state structures and processes on the basis of the foundation laid under colonialism. This is typically the case with Congo 
Ogirisi: a new journal of African studies vol 92012

Democratic Republic where nearly thirty years Mobutu Sese Seko strove to exceed Leopold II, the Belgian King's pillage of Congo and the use of state and its structures to intimidate, exploit and oppress the people of Congo. The fact of inorganic state structures as well as raison d' etre of European colonial enterprise largely explains the prevalent attitude of many of today's state institutions in Africa such as the army, police, prison officials, the courts, tax collectors (including custom officials and various other toll agents) and civil service in the absence of direct colonial supervision.

It is obviously on account of the foregoing, that Ake (in Okafor 2004: 90-91) laments that contemporary African states are "merely coercive force unable to transform power into authority and domination into hegemony". Yet, to be effective and stable, power must take the character of authority. This is because it is, strictly speaking, authority and ensures social acceptance. On its part, social acceptance is necessary, not only for organic relationship between institutions of the state and society at large, but also between policy formulation and implementation within specified social formation.

\section{Manipulated Severance from the Roots}

The reality of Africa's disconnection from her roots is also a critical dimension in the character and specificities of contemporary Africa. The word severance, comes from the verb to sever, that is to cut through in order to separate or to end for example, a relationship with someone or connection with something. The existence and mechanism of this disconnection occasioned by manipulated severance need to be put in the right perspective and understood.

Although, an aspect of Africa's attainments and preeminence during the Ethio- Egyptian epoch in terms of material and social sophistication and the achievements of 
Nnabugwu \& Nwanegbo: Dysfunctional State and Severance in Africa seventeenth century Sudanic states abound, no serious attempts have been made to explore, let alone revive, rejuvenate or repackage the heritage in contemporary Africa's attempt to confront the present day physical and social challenges. A typical example is the injunction of the Ethio-Egyptian Mystery System, which demanded specific lifestyle and code of behaviour for specific levels of the mystery school system.

The import of all these is that contemporary Africa is severed, largely deliberately, from the experiences of her roots. Mainstream thinking in contemporary Africa has been grafted into an insatiable, yet gullible quest for externally driven solutions to essentially internally generated problems and challenges. In the words of Davidson (1982) in "Ideology and Identity: An Approach from History"

Among the gullible, there was sixteen century king of Kongo (what is now northern Angola) who persuaded himself that his 'royal brother' of Portugal would send him useful technicians, including artisans capable of building a ship in which he could conduct his own trade with Europe outside the Portuguese royal monopoly (in Alavi and Shanin, 1982: 442).

Rather than these articles of genuine and autonomous development, what Nzinga a Mvemba, the Mani-Kongo of the Bakongo, who had earlier dropped his African names and titles, to become Dom Afonso I, King of the Congo and the Lord of the Ambundos got was "disastrous flood of Portuguese slavers" (Chinweizu: 28). It did not take long despite series of letters of appeal to King John III of Portugal, for the authority of even the Bakongo to be undermined and independence finally extinguished, through Bakongo's loss of the crucial battle of 1665 . 
Ogirisi: a new journal of African studies vol 92012

Similarly, in his work, The West and the Rest of Us Chinweizu (1978: 31) intimates us that: "...when African merchants of Calabar sought, at the beginning of the nineteenth century, to buy sugar-making equipment from England, the British refused to sell it to them lest they industrialize and compete with Britain's West India interest'. It is a pity that despite the dashed hopes and disappointments, and the inherent lessons therein, for Bakongo (Angola) kings and Calabar people of the past, who in the sixteen and nineteenth centuries, requested Europeans to build shipmaking and sugar-making factories respectively for them, many contemporary African leaders still believe that in this twenty-first century that foreign direct investment is the solution to the continent's vast socio-economic and political problems. Of course, like the Bakongo King, they are getting greater exploitation and underdevelopment rather than development and prosperity. Severance from the roots is thus a major factor in the character of today's Africa. However, the manipulated aspects of this severance need to be also highlighted.

The level of organization and sophistication of the African societies they met on ground as they moved in to claim their allocations generally surprised the dominant European powers of the Berlin Conference who gathered to divide up Africa. Using a combination of fraud, subterfuge and force of arms to establish themselves, they then set to work to deliberately undermine the technical development and societal institutions of the African societies they met. Where this was resisted, they (the Europeans) resorted to their superior force.

A case in point is the circumstances of the Arochukwu - British War, 1901 to 1902. The Arochukwu did not accept the dummy of protection from some distant Queen or King as a good enough reason to dismantle their vibrant and fairly 
Nnabugwu \& Nwanegbo: Dysfunctional State and Severance in Africa advanced technical iron works industry as proposed by the British. So, the British on some other excuse precipitated a war, defeated them, destroyed their entire iron technical works and outlawed their resuscitation. Thereafter, in deceitful magnanimity offered the Arochukwu society replacements of British made iron and technical products as compensation (Enemuo, 2011). This 'compensation' gesture was the precise point of severance from the age-long technical roots of the Arochukwu Igbo of Nigeria.

The process of deliberate or manipulated severance from Africa's roots was a widespread tactics of European hegemony in Africa. The native Arochukwu man or indeed most indigenous Africans of today hardly recognize iron ore any longer, let alone produce iron products; yet iron smelting or works was widespread not only among the Igbo - for example in Awka and Nkwerre (both in Southeast Nigeria) but also in many other parts of Africa before Europeans appeared on the shores from about the sixteen century AD. As it is today, and recognized by the British then, indigenous iron (and steel) management capability is the basis of modern progress in all its forms. Realizing then (as much as they do today), the usefulness and richness of Africa's past, the colonialists went to work to ensure the alienation of Africans with their useful past.

\section{Concluding Analysis}

In this paper we have problematized and argued on two major specificities that affect the character of contemporary Africa. They are first, the fact that the state and its attendant structures and processes imposed on Africa through colonial rule and bequeathed to her at flag is largely dysfunctional. Secondly, we have also pointed out that Africa has been manipulatively severed from her rich roots and heritage. 
Ogirisi: a new journal of African studies vol 92012

Against the backdrop of the foregoing and in line with subsisting recommendations in Biereenu-Nnabugwu (2005:171 - 173), we make four interrelated recommendations on the way forward. They are:

- Fresh Focus on African Studies

- Periodization of Africa Heritage

- Non-outward Oriented Institutions and Processes

- Self Driven Development

It is important to note that despite the obvious challenges confronting present day Africa, that Africa has a worthy heritage. There is urgent need to enrich current thought with the rich experience embedded in Africa's past. In this way, an organic interface with the roots would have to be forged for a better tomorrow.

*Makodi Biereenu-Nnabugwu $\boldsymbol{P h D}$ is a Senior Lecturer in the Department of Political Science, Nnamdi Azikiwe University, Awka

Email: nmakodi@yahoo.com

*Jaja Nwanegbo PhD is a Senior Lecturer in the Department of Political Science, Anambra State University, Igbariam Campus

Email: jajanwanegbo@yahoo.com 
Nnabugwu \& Nwanegbo: Dysfunctional State and Severance in Africa

\section{References}

Adetoro, J.E. (1976) A History Course for Junior Secondary Schools in Nigeria. Ibadan: MacMillan.

Ake, C. (1982) Social Science as Imperialism: The Theory of Political Development. Ibadan: Ibadan University Press

Alavi, H.and T. Shanin (1982) Introduction to the Sociology of "Developing Societies". London: Macmillan Press

Ancient Egypt (2007) MSN Encarta. http://ercanta.msn.com/encyclopedia

Baradat, L.P. (2008) Political Ideologies: Their Origins and Impact. New Delhi: Prentice-Hall

Ben-Jochannan, Y. (1970) Black Man of the Nile. New York: Aikebu-Lan Books.

Biereenu-Nnabugwu, M. (2007) "Reflection on the African Origin of the Thought-Content and Practices of Socrates" in

Biereenu-Nnabugwu, M. (2006) "Africa and the Origin of State Practice: Issues in Theory and Evolutionary Periods" in Osegbue, C. and N.A. Nwokoye, ed., The Dynamics of Africa Politics. Onitsha: Bookpoint.

Biereenu-Nnabugwu, M. (2005) Africa in the March of Civilization: An Outline of African Heritage. Enugu: CERPAHD Publication.

Biereenu-Nnabugwu, M. (2003) Political Theory: An Introductory Framework. Enugu: Quintagon Publishers.

Biereenu-Nnabugwu, M. and Nwanegbo, C. J. (2007) "Issues and Challenges of Communalism and Liberal Democratic Values among the Igbo of Nigeria", in Ike F. Odimegwu (eds.) Perspectives on African Communalism, Victoria, Canada: Trafford Publishing.

Buah, F.K. (1965) A New History for Schools and Colleges. London: Longmans

Chinweizu, (1978) The West and the Rest of Us. London: Nok.

Coregent, L. (1999) The African Continent: An Insight into its Earliest History. Nairobi: Paulines Publications.

Davidson, B. (1992) The Blackman's Burden: Africa and the Curse of the Nation-State. Ibadan: Spectrum

Davidson, N. (1991) Was Socrates a Plagiarist? In National Review http://www.encyclopedia.com/doc 
Ogirisi: a new journal of African studies vol 92012

ferrante, J (2003) Sociology: A Global Perspective ( ${ }^{\text {th }}$ Edition), C.A: Thomson Learning Academic Resource Centre.

Frolov, I. (1984) Dictionary of Philosophy. Moscow: Progress Publishers.

Gamble, A. (1981) An Introduction to Modern Social and Political Thought. London: Macmillan Press Ltd.

Gauba, O.P. (2003) An Introduction to Political Theory. Delhi: Macmillan. Gould and Thursby, eds (1969) Contemporary Political Thought: Issues in Scope, Value and Direction. New York: Holt, Rinehart and Winston.

Hobb, A. (2003) "Plato" in McLean and McMillan ed., The Concise Oxford Dictionary of Politics. New York: Oxford University Press.

Huntary, Orua. (1991) Traditional African Environment: The Science, History and Thought Processes. Lagos: Touche.

Igwe, O. (2005) Politics and Globe Dictionary. Aba: Eagle Publications

Iliffe, J. (1999) Africans: The History of a Continent. Cambridge: Cambridge University Press.

Johari, J.C. (1987) Contemporary Political Theory. New Delhi: Sterling Publishers.

Markovitz, I.L. (1977) Power and Class in Africa: An Introduction to Change and Conflicts in African Politics. Englewood Cliffs: Prentice-Hall.

Motley, M.P. (1969) Africa: Its Empires, Nations and People. Detroit: Wayne State University Press.

Mukherjee, S. and S. Ramaswamy (2005) A History of Political Thought: Plato to Marx. New Delhi: Prentice-Hall.

Nnoli, O. (2003) Introduction to Politics. Enugu: PARCEP.

Nwanegbo, C.J. (2005) "Poor Attitudinal Values and Democratic Principles in Nigeria: Adopting a Reform for Nigerian Electoral System", in Ogirisi: A New Journal of African Studies, Vol. 2. No.2. January. Pages 86-101. (Published in Victoria Canada by Trafford Publishing).

Nwanunobi, C.O. (2001) African Social Institutions. Nsukka: University of Nigeria Press.

Omoregbe, J. (1991) A Simplified History of Western Philosophy: Ancient and Medieval. Ikeja: Joja Publishers.

Onwuejeogwu, M A., B. Okpu, and C. Ebighgbo (2000) African Civilizations: Origin, Growth and Development. Lagos: Uto Publications 
Nnabugwu \& Nwanegbo: Dysfunctional State and Severance in Africa

Onyewuenyi, I. (1993) The African Origin of Greek Philosophy: An Exercise in Afrocentrism. Nsukka: University of Nigeria Press.

Olisa, M.S.O and Nwanegbo, C. J.(2006) "Traditional Democracies and National Democratic Spirit: A Prognostic Analysis" Paper presented at the $25^{\text {th }}$ Annual National Conference of Nigerian Political Science Association (NPSA), on the Theme: Democratic Processes and Institutions in Nigeria, held at Banigo Hall, University of Port-Harcourt, $27^{\text {th }}-31^{\text {st }}$ August, 2006. Published at the NPSA Proceedings tiled Electoral Reforms, Political Succession and Democratization in Africa, vol. 1, pages 39 61Robertson, D. (1993) Penguin Dictionary of Politics. London: Penguin Books.

Rodney, W. (1972) How Europe Underdeveloped Africa. London: BogleL'Ouverture.

Sabine, G.H. and T.L. Thornson (1973) A History of Political Theory. Delhi: Oxford and IBH Publishing.

Sanford, E.M. (1951) The Mediterranean World in Ancient Times. New York: Ronald Press.

Sibley (1958) "The Place of Classical Political Theory in the Study of Politics: The Legitimate Spell of Plato" in Young, R. ed., Approaches to the Study of Politics. Evanstone: Northwestern University Press.

Stace, W.T. (1963) (1969) A Critical History of Greek Philosophy. New York: Macmillan.

Thomson, (1969) in Thomson, ed. Political Ideas. Harmondsworth: Macmillan.

Toyo, E. (2007) Globalization from a Perspective Relevant to Africa. Calabar: Confident Options.

Zehar, R (1974) Colonialism and Alienation: Political Thoughts of Frantz. Fanon. Benin:Ethiope Publishing Corporation 